\title{
Activin B is produced early in antral follicular development and suppresses thecal androgen production
}

\author{
J M Young, S Henderson, C Souza 1 , H Ludlow ${ }^{2}$, N Groome ${ }^{2}$ and A S McNeilly \\ MRC Human Reproductive Sciences Unit, The Queen's Medical Research Institute, 47 Little France Crescent, \\ Edinburgh EH16 4TJ, UK, ${ }^{1}$ Embrapa Pecuaria Sul, Bage, Brazil and ${ }^{2}$ Oxford Brookes University, Gipsy Lane Campus, \\ Headington, Oxford OX3 OBP, UK
}

Correspondence should be addressed to J M Young who is now at Monash Institute of Medical Research, Centre for Reproduction and Development, 27-31 Wright Street, PO Box 5418, Clayton, Victoria 3168, Australia; Email: julia.m.young@monash.edu

$\mathrm{H}$ Ludlow is now at Syntaxin Ltd, Units 4-10 The Quadrant, Barton Lane, Abingdon OX14 3YS, UK

N Groome is now at Ansh Labs LLC, 445 Medical Centre Boulevard, Webster, Texas 77598, USA

A S McNeilly is now at MRC Centre for Reproductive Health, The Queen's Medical Research Institute, 47 Little France Crescent, Edinburgh EH16 4TJ, UK

\begin{abstract}
Little is known about the role of activin $B$ during folliculogenesis. This study investigated the expression levels of activin/inhibin subunits $(\beta A, \beta B$, and $\alpha)$, steroid enzyme, and gonadotrophin receptors in theca (TC) and granulosa cells (GC) by QPCR and activin A and B and inhibin A protein levels in follicular fluid (FF) of developing sheep follicles during estrus and anestrus. The effect of activin $B$ on androgen production from primary TC cultures in vitro was also assessed. During folliculogenesis, in anestrus and estrus, FF activin B

concentrations and thecal and GC activin $\beta B$ mRNA levels decreased as follicle diameter increased from 1-3 to $>6$ mm regardless of estrogenic status. Estrogenic preovulatory follicles had reduced concentrations of FF activins B and A, and TC and GCs expressed higher levels of activin $\beta A$ mRNA at 3-4 mm, and TCs more inhibin $\alpha$ mRNA at $>4 \mathrm{~mm}$ stages of development compared with nonestrogenic follicles. Activin B decreased androstenedione production from primary TCs in vitro, an effect blocked by inhibin A. Thus, sheep follicles 1-3 mm in diameter contained high FF levels of activin B, which decreased as the follicle size increased, and, like activin A, suppressed thecal androgen production in vitro, an effect blocked by inhibin. Furthermore, the theca of large estrogenic follicles expressed high levels of inhibin $\alpha$ and activin $\beta A$ mRNA suggesting local thecal derived inhibin A production. This would inhibit the negative effects of thecal activins $B$ and A ensuring maximum androgen production for enhanced estradiol production by the preovulatory follicle(s).

Reproduction (2012) $143637-650$
\end{abstract}

\section{Introduction}

Activin and inhibin are members of the TGF $\beta$ superfamily that consists of over 40 ligands including the bone morphogenetic proteins (BMPs), myostatin, and growth and differentiation factors (GDFs; Knight \& Glister 2006). Activin and inhibin were originally identified from ovarian follicular fluid (FF) and have since been implicated in many ovarian processes necessary for normal and successful follicle development.

Structurally, activins are disulfide-linked dimers, where activin $A$ and activin $B$ are homodimers of activin $\beta A$ and $\beta B$ subunits respectively. Inhibin is composed of an $\alpha$ subunit heterodimerized with either a $\beta A$ (inhibin $A$ ) or a $\beta B$ (inhibin B) subunit (Knight et al. 2011). Activins signal through the SMAD2/3 pathway by interacting with one of the two activin type II receptors (ACVR2A (actRIIA) or ACVR2B (actRIIB)), which heterodimerize with the type I activin receptor ACVR1B (actRIB). The activin type IB receptor (also known as ACVR1B (ALK4)) is commonly regarded as the receptor that activins use, but activins $B$ and activin $A B(\beta A / \beta B$ heterodimer) might also signal through the type IC activin receptors (ACVR1C (ALK7)) (Bernard et al. 2006). The type I receptor initiates a signaling cascade by activating a phosphorylation cascade through SMAD2/3 that complexes with SMAD4 and translocates to the cell nucleus to modulate gene transcription. The effects of activin are antagonized by inhibin, which acts by blocking activin binding to its receptors and by follistatin, which forms complexes with activin extracellularly preventing activin availability (Knight et al. 2011).

Inhibins and activins are made by cells of the developing follicle and accumulate in high concentrations in the antral FF. Previous studies have shown that 
granulosa cells (GCs) are the major source of follicular inhibin, which acts in a feedback mechanism to the pituitary to modulate gonadotrophin production (Padmanabhan \& McNeilly 2001, McNeilly et al. 2003). Mouse models were used to investigate the importance of activin in development and fertility. Mice lacking the activin $\beta A$ subunit are neonatal lethal (Matzuk et al. 1995) while activin $\beta B$ null mice survived to adulthood (Vassalli et al. 1994). Activin B-deficient male mice exhibited normal fertility; however, females displayed profound inability to reproduce and their offspring are perinatal lethal. A GC-specific conditional activin $\beta A$ knockout mouse was created and was subfertile (Pangas et al. 2007), and the same observation was found when mature $\beta A$ was replaced with mature $\beta B$ (Brown et al. 2000). These findings suggest that both activins $A$ and $B$ are important for regulating ovarian function and that activin $B$ is necessary for female fertility. However, limited research has been carried out to determine the presence and function of activin B in somatic follicular cells due to a lack of specific assays for measuring activin $B$. While it was thought that activin $B$ functions simply as an alternative to activin $\mathrm{A}$, at least in thecal cells (TCs) from cattle activin B appears to have no activity while activin A will suppress androgen production (Knight et al. 2011). In sheep while the activin $\beta B$ subunit mRNA and protein is expressed in both the testis and the ovary, no inhibin B is produced, and inhibin $A$ is the only form produced and secreted by the testes and ovaries (McNeilly et al. 2002). These findings are interesting given that activin B is present during follicle development, and inhibin B functions during the follicular phase in human folliculogenesis but does not appear to be necessary for sheep fertility (McNeilly et al. 2002).

We have now used a new specific ELISA for activin B (Ludlow et al. 2009) to investigate the role of activin B in folliculogenesis. Using sheep, we determined the potential role of activin B in modulating thecal androgen production in vitro and the pattern of production of activin B in vivo when follicular development continues in the face of low LH pulse frequencies in anestrus (McNeilly et al. 1982), when LH pulse frequency is highest in the late follicular phase of the normal cycle (Wallace et al. 1988), and after an induced preovulatory LH surge at a time when estradiol $\left(E_{2}\right)$ and androgen production is suppressed before ovulation (Baird et al. 1981). In these studies, the concentration of $F F E_{2}$ was also measured and used to determine follicle dominance to compare levels of gene expression and protein accumulation in follicles in different states of health. Previous studies have shown that in follicles $>2.5 \mathrm{~mm}$ in diameter, the size beyond which follicles are gonadotrophin dependent in sheep (McNeilly et al. 1986, 1987, McNeilly \& Fraser 1987), FF levels of $E_{2}$ directly reflect the state of health or atresia of follicles (Carson et al. 1981). High levels of $E_{2}$ reflect healthy preovulatory follicles expressing high levels of $\mathrm{LH}$ receptors in both GCs and TCs (Webb \& England 1982), and this is correlated with high output of $E_{2}$ when the individual follicles are incubated in vitro (Webb \& England 1982, McNeilly \& Fraser 1987, McNeilly et al. 1987). In contrast, low levels of $\mathrm{E}_{2}$ both in $\mathrm{FF}$ and in in vitro culture are associated with follicles in varying states of atresia producing high levels of androgens (Carson et al. 1981, Webb \& England 1982).

The objectives of this study were to measure the concentrations of activin $B$ in FF and compare with those for activin $A$, inhibin $A$, and the estrogenic status of each individual follicle and correlate these measurements with the expression patterns of activin subunits $(\beta A, \beta B)$, inhibin $\alpha$, gonadotrophin receptors, and components of the steroidogenic pathway in TCs and GCs.

\section{Results}

\section{Changes in activin $B$ during folliculogenesis}

The mean concentrations of activin $\mathrm{B}, \mathrm{A}$, and inhibin $\mathrm{A}$, in the FF of follicles collected from sheep during anestrus, and the follicular phase (preovulatory and post-LH surge) are shown in Fig. 1. The concentrations of $E_{2}$ were measured in the antral fluid of each follicle to allow segregation of follicles based on estrogenic status and are graphed into high and low estrogenic groups reflecting the dominant or subordinate status of each follicle respectively.

The results showed that levels of $E_{2}$ were significantly lower in the antral fluid of follicles during anestrus compared with follicles during the follicular phase of the estrous cycle $(P<0.05)$ (data not shown). There was also a significant decrease in the concentration of $E_{2}$ following the $\mathrm{LH}$ surge in follicles $1-3,3-4$, and $>6 \mathrm{~mm}$ in diameter $(P<0.001)$. The greatest concentration of $E_{2}$ was found in preovulatory follicles $>6 \mathrm{~mm}$ in size $(9449 \pm 1700 \mathrm{ng} / \mathrm{ml})$.

\section{Antral activin B concentration decreased as follicle size increased}

Measurements showed that activin B concentration decreased $(P<0.001)$ as follicle size increased during the three reproductive phases tested regardless of the estrogenic content of follicles (Fig. 1). At the small antral stage (1-3 $\mathrm{mm}$ in diameter), the average activin B concentration was $877 \pm 47 \mathrm{ng} / \mathrm{ml}$, from 3-4 mm was $359 \pm 18 \mathrm{ng} / \mathrm{ml}, 173 \pm 17 \mathrm{ng} / \mathrm{ml}$ from $4-6 \mathrm{~mm}$, and at $>6 \mathrm{~mm}$ follicular activin $\mathrm{B}$ concentrations decreased to $72 \pm 6 \mathrm{ng} / \mathrm{ml}$.

Significant differences were observed between the levels of activin B and the phase of the reproductive cycle within each follicle size group assessed. Small follicles $(1-3 \mathrm{~mm})$ from ovaries of sheep during anestrus had significantly less antral activin $B$ than follicles during the follicular phase of the estrous cycle $(P<0.01)$. 

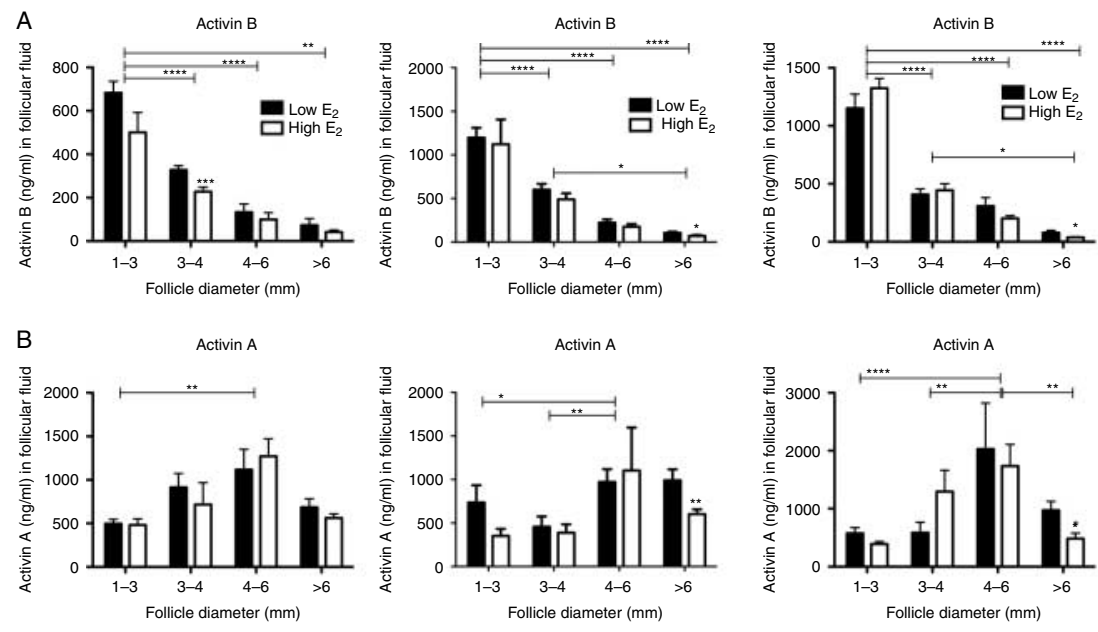

Figure 1 Follicular fluid concentrations of activin
$\mathrm{A}, \mathrm{B}$, and inhibin $\mathrm{A}(\mathrm{ng} / \mathrm{ml})$ during $(\mathrm{A})$ anestrus
$(n=10$ sheep), (B) preovulatory ( $n=10$ sheep),
and $(\mathrm{C})$ after the $\mathrm{LH}$ surge ( $n=10$ sheep) in
follicles $1-3$ to $>6 \mathrm{~mm}$ in diameter. Data shown
are the average \pm s.E.M. concentration $(\mathrm{ng} / \mathrm{ml})$ for
all follicles in each size group. Significance was
calculated between estrogenic (white bars) and
nonestrogenic (black bars) groups using Student's
$t$-test $(* P<0.05, * * P<0.01$, and $* * * P<0.001$,
$* * * * P<0.0001)$. Significance of differences
between groups is also indicated above the graphs
and is calculated on the average for each size class
regardless of the follicular estrogenic status.
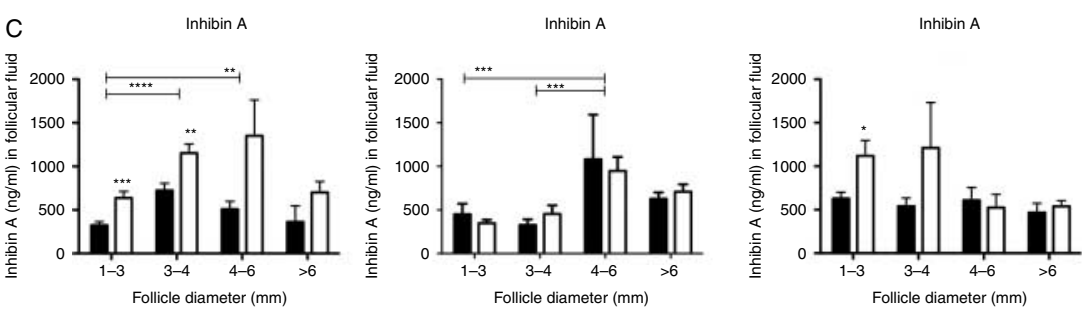

The concentration of activin B increased after the $\mathrm{LH}$ surge by $\sim 30 \%$ from those concentrations observed in follicles just before the $\mathrm{LH}$ surge $(P<0.05)$. In follicles measuring 3-4 and 4-6 $\mathrm{mm}$ in diameter, activin $B$ levels were significantly lower during anestrus $(P<0.001)$, but no significant differences were found between stages of the follicular phase (prior and post-LH surge). No differences in FF activin B concentrations were observed between cycling and anestrus follicles $>6 \mathrm{~mm}$ in diameter, nor were any differences found preceding and following the preovulatory LH surge in follicles of this size.

When follicles were segregated based on the estrogenic status, the results showed that levels of FF activin $B$ in estrogenic (high $\mathrm{E}_{2}$ ) preovulatory follicles $(>6 \mathrm{~mm}$ ) during the follicular phase were lower than nonestrogenic (low $E_{2}$ ) follicles, measuring $71 \pm 9$ and 106 $\pm 14 \mathrm{ng} / \mathrm{ml}$ respectively $(P<0.05$; Fig. $1 \mathrm{~B})$. The concentration was also reduced after the $\mathrm{LH}$ surge in follicles $>6 \mathrm{~mm}$ in diameter (Fig. 1C). During the anestrus phase, estrogenic follicles 3-4 mm in diameter had lower FF activin $B$ levels than nonestrogenic follicles of the same size $(P<0.001$; Fig. 1A). No other differences between estrogenic and nonestrogenic follicle activin $\mathrm{B}$ concentrations were observed.

\section{Activin A and inhibin A levels follow a similar pattern}

The levels of activin $A$ and inhibin $A$ were measured from the same follicles used to map activin B concentrations. Data for all phases were averaged within size groups, and results showed that the concentration of activin A increased from $474 \pm 34 \mathrm{ng} / \mathrm{ml}$ in small antral follicles $(1-3 \mathrm{~mm})$ to $822 \pm 104 \mathrm{ng} / \mathrm{ml}$ in $3-4 \mathrm{~mm}$, $1338 \pm 160 \mathrm{ng} / \mathrm{ml}$ in large antral follicles $(4-6 \mathrm{~mm})$, after which the levels of activin A in the FF decreased to $734 \pm 54 \mathrm{ng} / \mathrm{ml}(P<0.001)$ as follicles approached preovulatory size ( $>6 \mathrm{~mm})$.

The concentration of antral inhibin A followed a similar pattern to that of activin A. The average concentration of FF inhibin in follicles, regardless of cyclic stage, increased from $526 \pm 37 \mathrm{ng} / \mathrm{ml}$ in $1-3 \mathrm{~mm}$ follicles to $849 \pm 86 \mathrm{ng} / \mathrm{ml}$ in $3-4 \mathrm{~mm}, 827 \pm 110 \mathrm{ng} / \mathrm{ml}$ in $4-6 \mathrm{~mm}$, and then significantly decreased to 591 $\pm 40 \mathrm{ng} / \mathrm{ml}$ in follicles $>6 \mathrm{~mm}$ in diameter $(P<0.05)$. Moreover, differences were found between inhibin A concentrations in 1-3 mm follicles during the three phases of the cycle assessed. The concentration of inhibin A was significantly higher $(P<0.001)$ measuring $830 \pm 99 \mathrm{ng} / \mathrm{ml}$ after the LH surge and only $476 \pm 45$ and $366 \pm 52 \mathrm{ng} / \mathrm{ml}$ before the $\mathrm{LH}$ surge and during anestrus respectively.

Estrogenic follicles $>6 \mathrm{~mm}$ in diameter had 602 $\pm 56 \mathrm{ng} / \mathrm{ml}$ and nonestrogenic follicles had 990 $\pm 130 \mathrm{ng} / \mathrm{ml} \mathrm{FF}$ activin A $(P<0.01)$, and a reduced level of FF activin A was also found after the LH surge in estrogenic follicles $>6 \mathrm{~mm}$ in diameter $(P<0.05)$. However, no other differences in activin A concentration were found between estrogenic and nonestrogenic follicles at other stages of development (Fig. 1).

No significant differences in FF inhibin A content were found between the estrogenic and nonestrogenic follicles during the follicular phase of the estrous cycle (Fig. 1B). However, higher levels of FF inhibin were 
observed after the $\mathrm{LH}$ surge in estrogenic follicles $1-3 \mathrm{~mm}$ in diameter $(P<0.05)$ and during anestrus in estrogenic follicles $1-3$ and $3-4 \mathrm{~mm}$ in diameter $(P<0.01)$.

\section{Activin $\beta B$ subunit expression during the reproductive cycle}

The follicles collected during anestrus, before and following the $\mathrm{LH}$ surge during the follicular phase of the estrous cycle, were divided into estrogenic and nonestrogenic based on the FF $E_{2}$ concentrations.

The five follicles with the highest and five with the lowest levels of $F F E_{2}$ within each size group (1-3, 3-4, $4-6$, and $>6 \mathrm{~mm}$ diameter) for each phase of the cycle (anestrus, preovulatory, and after the LH surge) were then selected for gene expression studies. Follicles were collected from $n \geq 3$ sheep for each group analyzed. Each follicle was treated separately, and no pooling of mRNA or FF from individual follicles was carried out within this study.

The expression levels of mRNA encoding activin $\beta A$, $\beta B$, and inhibin $\alpha$ subunits were measured in TC and GC, and estrogenic follicles were found to have differential expression levels at specific stages of development.

During anestrus (Fig. 2), estrogenic follicles $1-3 \mathrm{~mm}$ in diameter expressed more mRNA encoding $\beta A, \beta B$, and $\alpha$ in TCs $(P<0.05)$ and more $\alpha$ in GCs $(P<0.001)$. Follicles from 3 to $4 \mathrm{~mm}$ in diameter produced more $\beta$ A in TCs and more $\alpha$ and $\beta$ A in GCs $(P<0.05)$. Follicles $>4 \mathrm{~mm}$ in diameter were not found to have any differential levels between estrogenic and nonestrogenic follicles. There was a significant difference between the levels of $\beta A$ mRNA expressed between thecal cells in those follicles from 1 to $3 \mathrm{~mm}$ in diameter compared with follicles of $4-6 \mathrm{~mm}$ in diameter $(P<0.05)$.

During the preovulatory phase of estrus (Fig. 3), TC and GCs from 3 to $4 \mathrm{~mm}$ estrogenic follicles produced higher levels of $\beta A$ mRNA than nonestrogenic follicles. TCs from follicles $4-6$ and $>6 \mathrm{~mm}$ in diameter produced higher levels of $\alpha$ subunit $(P<0.05)$, and TCs from follicles $>6 \mathrm{~mm}$ also produced more $\beta A$ mRNA $(P<0.01)$. No differences were observed in GC expression between estrogenic and nonestrogenic follicles in follicles $>4 \mathrm{~mm}$ in diameter during the preovulatory phase. Significant differences were found between expression levels of the $\alpha$ subunit in TCs of follicles 1-3 mm compared with follicles $>6 \mathrm{~mm}$ in diameter $(P<0.05)$ and between follicles $3-4$ and $>6 \mathrm{~mm}(P<0.05)$.

After the LH surge (Fig. 4), TCs from estrogenic follicles $1-3 \mathrm{~mm}$ in diameter produced higher levels of mRNA encoding $\beta \mathrm{A}, \beta \mathrm{B}$, and $\alpha$ subunits $(P<0.05)$, and GCs produced more $\alpha$ mRNA $(P<0.001)$. TCs from estrogenic follicles $4-6 \mathrm{~mm}$ in diameter had reduced levels of $\beta A$ subunit expression $(P<0.01)$. Significant differences were found between expression levels of $\beta$ A subunit in
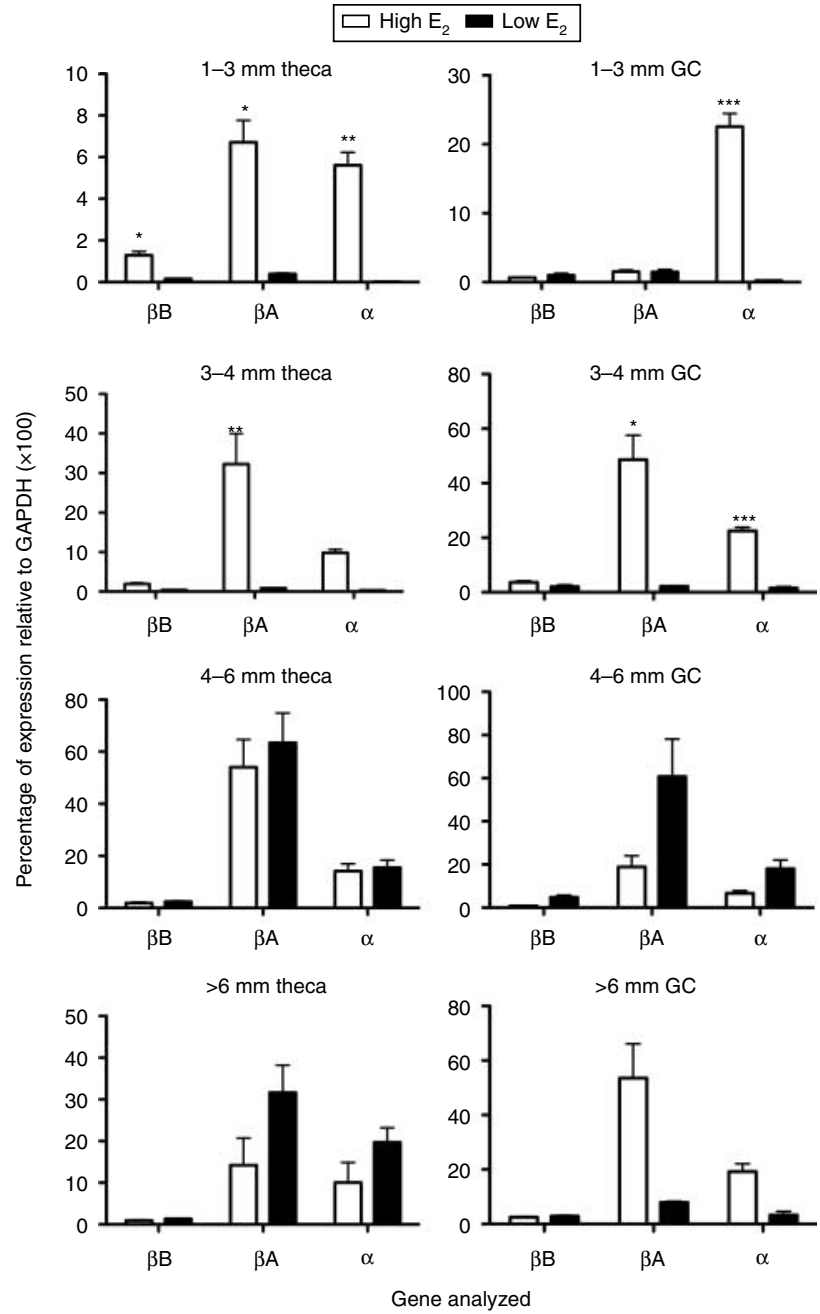

Figure 2 Follicles collected during anestrus. Gene expression levels for activin and inhibin subunits $\beta \mathrm{A}, \beta \mathrm{B}$, and alpha $(\alpha)$ in theca and granulosa (GC) cells of follicles (1-3 to $>6 \mathrm{~mm}$ in diameter). Follicles were segregated based on FF estrogenic content (high (white bars) and low (black bars) estrogen) $\left({ }^{*} P<0.05,{ }^{* *} P<0.01\right.$, and $\left.{ }^{* * *} P<0.001\right)$.

TCs of follicles from size categories: $1-3 \mathrm{~mm}$ compared with 4-6 mm $(P<0.01), 3-4 \mathrm{~mm}$ compared with 4-6 $\mathrm{mm}(P<0.01)$, and 4-6 mm compared with $>6 \mathrm{~mm}$ $(P<0.01)$ follicles. Differences were also observed for $\beta B$ expression: 1-3 $\mathrm{mm}$ compared with $4-6 \mathrm{~mm}$ $(P<0.001)$ and $4-6 \mathrm{~mm}$ compared with $>6 \mathrm{~mm}$ $(P<0.01)$.

In our study, low levels of inhibin $\alpha$ protein were present in the thecal layer with high levels present in GCs of preovulatory estrogenic follicles (Fig. 5C) identified by the expression of aromatase (Fig. 5A). In contrast, expression in the theca layer and GCs was either absent or at a low level in aromatase-negative follicles (Fig. 5C and $D)$. Activin $\beta A$ subunit was expressed in GCs and in the theca layer of both aromatase-positive and -negative follicles (Fig. 5E and F). Future studies will be required to determine the exact cell types that are expressing both 

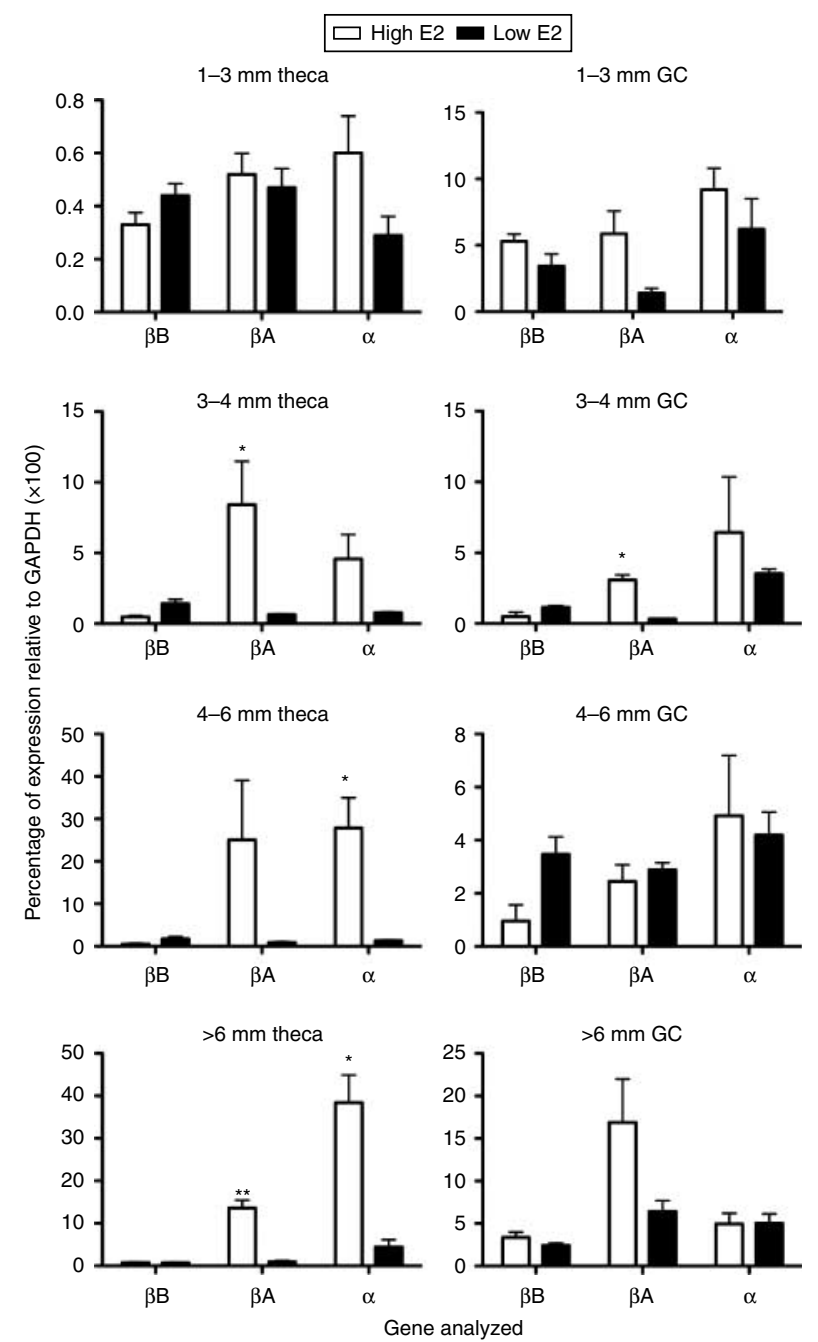

Figure 3 Follicles collected during the preovulatory phase. Gene expression levels for activin and inhibin subunits $\beta A, \beta B$, and alpha $(\alpha)$ in theca and granulosa (GC) cells of follicles (1-3 to $>6 \mathrm{~mm}$ in diameter). Follicles were segregated based on FF estrogenic content (high (white bars) and low (black bars) estrogen) $\left({ }^{*} P<0.05,{ }^{* *} P<0.01\right.$, and $* * * P<0.001)$.

subunits within the thecal layer and therefore potentially contributing to the inhibin that controls androgen production.

\section{Expression levels in components of steroidogenic pathway}

During anestrus (Fig. 6), TCs from estrogenic follicles $1-3$ to $4 \mathrm{~mm}$ in size produced less mRNA encoding StAR and more mRNA encoding CYP17A1 (CYP17) and $3 \beta H S D(P<0.05)$. Estrogenic follicles $3-4 \mathrm{~mm}$ in size produced higher levels of CYP19A1 (CYP19) mRNA in GCs during anestrus $(P<0.05)$, and higher expression of $F S H R$ and $3 \beta H S D$ was found in GCs of estrogenic follicles $3-4 \mathrm{~mm}$ in diameter $(P<0.05)$. Significant differences between expression levels of different follicle sizes are shown on the graphs in Fig. 6.
TCs from preovulatory follicles (Fig. 7) of $3-4 \mathrm{~mm}$ in diameter expressed more mRNA encoding $3 \beta \mathrm{HSD}$ $(P<0.05)$, and follicles $>6 \mathrm{~mm}$ were found to have more StAR $(P<0.01)$ and CYP17A1 $(P<0.05)$ mRNA. No differences were found between estrogenic and nonestrogenic follicles during the preovulatory phase in levels of mRNA encoding $L H R, F S H R, C Y P 19 A 1$, and $3 \beta H S D$. Differences between the expression levels and size groups are displayed on the graphs in Fig. 7 (calculated grouped into sizes regardless of estrogenic status).

After the LH surge (Fig. 8), TCs from estrogenic follicles $4-6 \mathrm{~mm}$ in diameter contained more StAR and $3 \beta H S D$ mRNA $(P<0.05)$ and $>6 \mathrm{~mm}$ estrogenic follicles had lower levels of mRNA encoding StAR and $L H R(P<0.05)$. GCs from estrogenic follicles $1-3 \mathrm{~mm}$ in diameter expressed more CYP19A1 and 4-6 mm expressed less $3 \beta H S D$ mRNA $(P<0.05)$. Significant differences between expression levels of each follicle size group, regardless of estrogenic status, were calculated and are shown on the graphs in Fig. 8.

\section{Activin B suppresses androstenedione production}

Sheep TCs cultured in vitro in the presence of $1 \mathrm{ng} / \mathrm{ml}$ activin B produced $85 \%$ less androstenedione than control cells (Fig. 9). At concentrations of 10 and 100 ng/ $\mathrm{ml}$, activin $\mathrm{B}$ reduced androstenedione production by 93 and $99 \%$ compared with control levels $(P<0.001)$. The effects of activin $B$ were similar to levels observed for activin A-treated cells, which were also significantly suppressed in the presence of activin A ( $83 \%$ less than control levels at $1 \mathrm{ng} / \mathrm{ml}, P<0.001$ ).

Inhibin A treatment at $1 \mathrm{ng} / \mathrm{ml}$ increased androstenedione production by $88 \%$ compared with the control level $(P<0.001)$ and was also able to block the suppressive effects of activin B $(79 \%$ increase $)$ and activin A $(70 \%$ increase $)(P<0.01)$ at $100 \mathrm{ng} / \mathrm{ml}$. The effects of activin and inhibin treatment did not alter cell viability as determined by neutral red assays (data not shown).

\section{Discussion}

This study provides novel information on the expression patterns and concentration profile of activin B in antral fluid of individual sheep follicles during follicular development in anestrus and during the follicular phase of the estrous cycle before and after the preovulatory LH surge when follicles are exposed to radically different patterns of pulsatile $\mathrm{LH}$ secretion. Historically, activin B was thought to function similarly to activin $A$, albeit with less potency suggesting perhaps the use of different receptors for activin B (Corrigan et al. 1991, Mathews \& Vale 1991, Nakamura et al. 1992). This study shows that the expression patterns of activin 

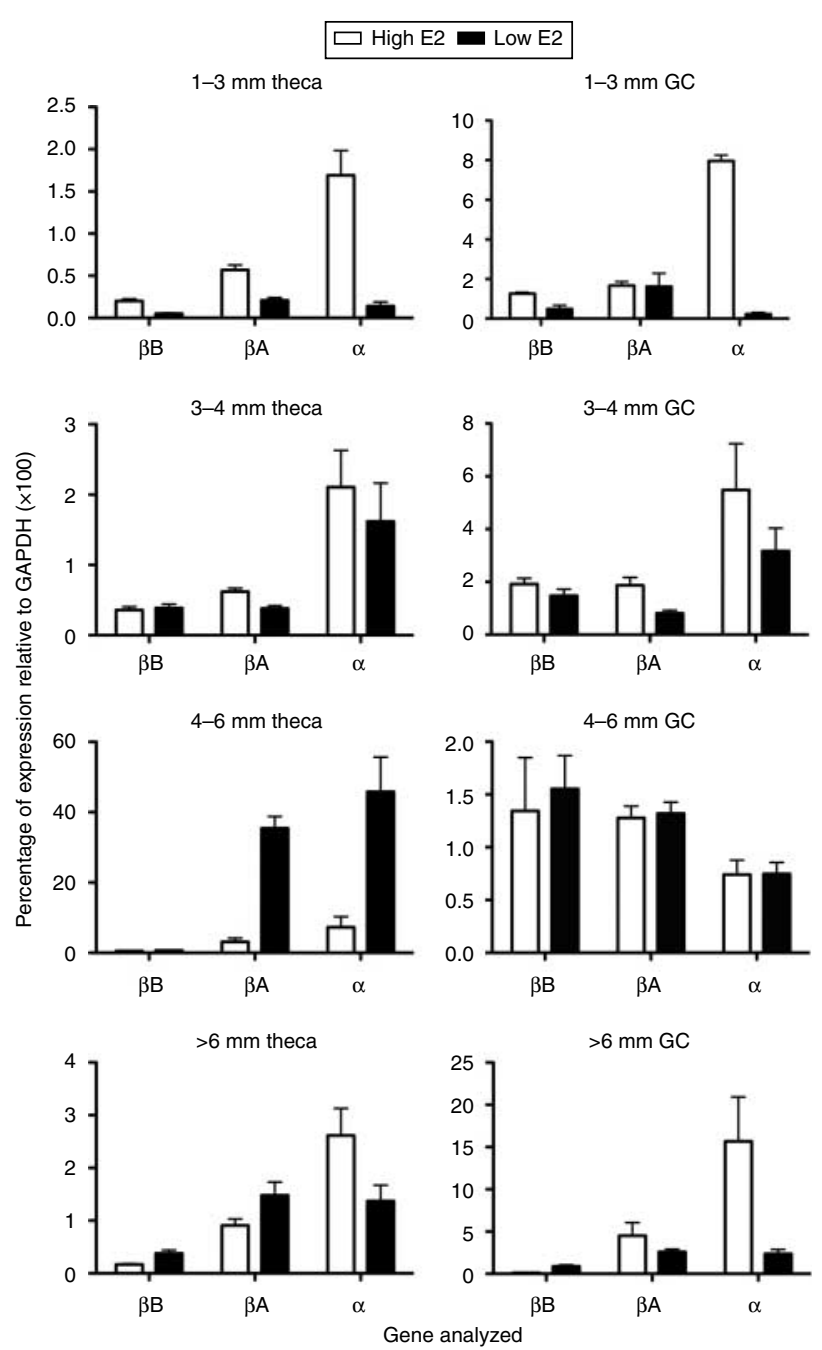

Figure 4 Follicles collected after the LH surge of estrus. Gene expression levels for activin and inhibin subunits $\beta \mathrm{A}, \beta \mathrm{B}$, and alpha $(\alpha)$ in theca and granulosa (GC) cells of follicles $(1-3$ to $>6 \mathrm{~mm}$ in diameter). Follicles were segregated based on FF estrogenic content (high (white bars) and low (black bars) estrogen).

$\beta B$ differ from activin $\beta A$ during follicle development. The patterns of activins $A$ and $B$ protein concentrations in FF are disparate, indicating a potentially independent role for activin $B$ during folliculogenesis. The results of this study show that activin B suppresses in vitro thecal androgen production to a similar level as activin $\mathrm{A}$ and that the effects of both activins $A$ and $B$ are blocked by inhibin A.

The concentration of FF activin B protein was highest at early antral stages of development and decreased as follicle size increased. From the primary stage of folliculogenesis, there is evidence that sheep GCs can synthesize activin $\beta B$ subunit as well as inhibin and follistatin, and from the small antral stage, activin $\beta A$ is found (McNatty et al. 2007). This study shows that activin $\beta B$ mRNA is produced in TCs and GCs in varied quantities throughout antral follicle development.
The abundance of mRNA transcripts encoding activin/ inhibin subunits $(\beta \mathrm{A}, \beta \mathrm{B}$, and $\alpha)$ and steroidogenic pathway components (LHR, FSHR, $3 \beta \mathrm{HSD}$, StAR, CYP17A1, and CYP19A1) were quantified in GC and/or TCs isolated from follicles ranging in diameter from 1-3 (small antral) to $>6 \mathrm{~mm}$ (preovulatory). Follicles of these sizes were assessed due to the presence of antral fluid because these follicles contained sufficient GCs and TCs for individual follicle expression analyses and because this size range covers several important developmental stages. During these stages of development, follicles undergo the transition from gonadotrophin independence to becoming dependent (McNeilly et al. 1986), are selected for dominance, acquire LH receptors and necessary steroidogenic pathway components, produce higher levels of androgens and $E_{2}$, and become dominant (estrogenic) in preparation for ovulation (Scaramuzzi et al. 1993, 2011, McNatty et al. 2007). The mechanism by which follicle dominance occurs in sheep is not well described (McNeilly et al. 1991, Scaramuzzi et al. 1993, 2011). Nevertheless, those follicles on a dominant growth track do have significantly higher levels of antral fluid $E_{2}$ than those destined for atresia (Carson et al. 1981, Webb \& England 1982). Therefore, in this study, antral $E_{2}$ concentrations were measured and follicles segregated into dominant and subordinate follicle populations. While there is insufficient pulsatile LH support for high-level steroid production to occur during anestrus, follicles remain in a continuous cycle of growth and regression without actually reaching the point of ovulation. This study shows that there are differences in antral activin B and inhibin A protein concentrations between small $(<4 \mathrm{~mm})$ dominant follicles during anestrus, at a stage of development where follicle growth would normally be transitioning into gonadotrophin dependence during estrus. However, as follicles continue to grow in the gonadotrophin-dependent phase, the differences in activin and inhibin levels between dominant and subordinate follicles are lost. Aromatase expression in GCs from these follicles is also deficient, and no differences were found between estrogenic and nonestrogenic follicles in any genes assessed once follicles reached $4 \mathrm{~mm}$ in diameter. These results suggest that induction of aromatase and other steroidogenic enzymes in both TCs and GCs, even in large healthy estrogenic follicles, is dependent on the frequency of LH pulses that is limited in anestrus. This is supported by previous studies that showed that normal follicle steroid production is induced when LH pulses alone are replaced during anestrus (McNeilly et al. 1982, Wallace et al. 1986).

During the follicular phase of the estrous cycle, decreased concentrations of activins $B$ and $A$ were found in antral fluid from large dominant preovulatory follicles in comparison with subordinate size-matched follicles. At the preovulatory stage of 
A

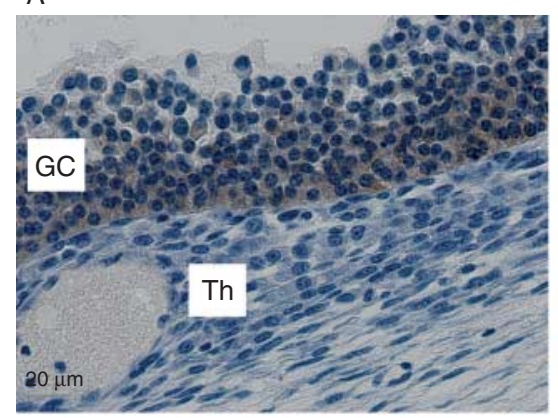

C
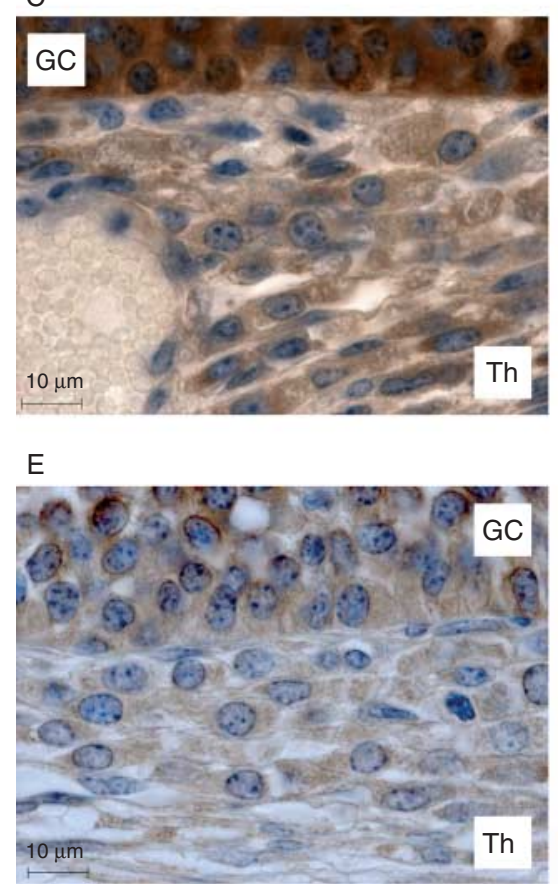

B

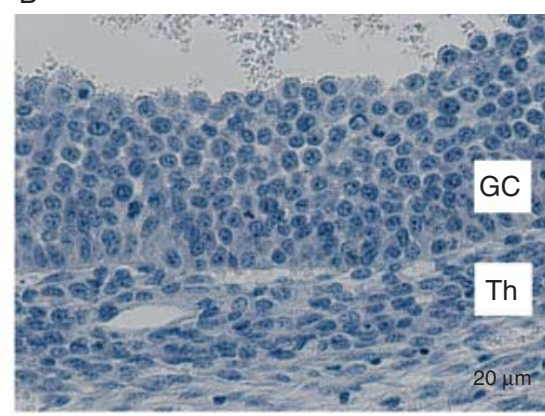

D

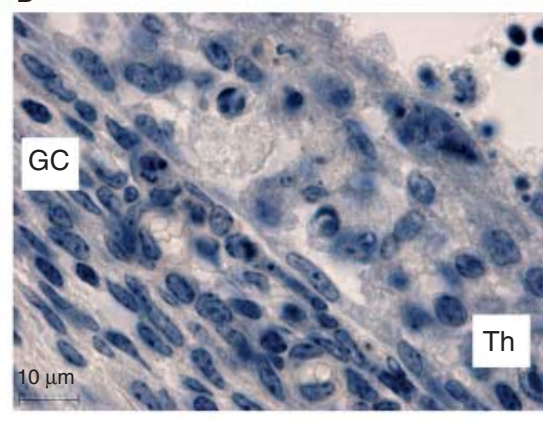

$\mathrm{F}$

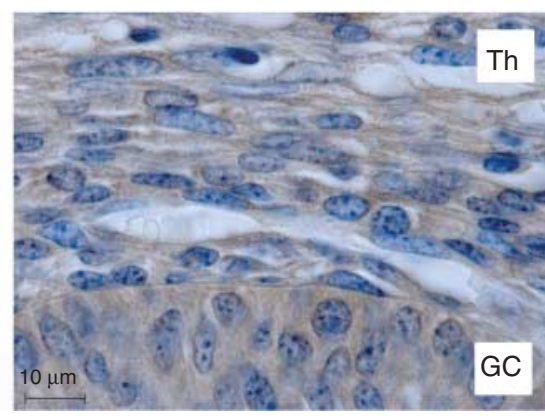

Figure 5 Immunohistochemistry for aromatase (A and $B)$, inhibin $\alpha(C$ and $D)$, and activin $\beta A$ subunit ( $E$ and $F$ ) in an aromatase-positive estrogenic ( $A, C$ and $\mathrm{E}$ ) and aromatase-negative nonestrogenic (B, $\mathrm{D}$ and $\mathrm{F}$ ) large follicles in an ovary taken in the follicular phase of the estrous cycle $36 \mathrm{~h}$ after prostaglandin injection. Th, thecal layer; GC, granulosa cells. development, androgens are required in larger quantities as precursors for $E_{2}$ synthesis in neighboring GCs (Young \& McNeilly 2010). This study confirms previous reports that activin $\mathrm{A}$ reduces androgen production (Hillier et al. 1991) and shows that activin B suppresses androgen production from TCs cultured in vitro, and it is not unexpected that follicles producing higher levels of antral $E_{2}$ also have lower levels of activins. At this preovulatory stage, inhibin is produced as an important feedback mechanism signaling to the pituitary gland to modulate FSH secretion. A significant increase in inhibin A levels was observed in antral fluid of estrogenic follicles $1-3 \mathrm{~mm}$ in diameter after the ovulatory $\mathrm{LH}$ surge. In sheep, only inhibin A is produced (McNeilly et al. 2002), and thus, the increased expression of inhibin $\alpha$ in both the TCs and the GCs of larger follicles that was observed would result in de novo synthesis of inhibin $\alpha$ subunit and heterodimerization with activin $\beta A$ to produce inhibin $A$ rather than forming homodimers of $\beta A$. In this instance, inhibin $A$ would function to reduce activin $\mathrm{A}$ production and also to increase androgen production by blocking the suppressive effects of residual activins $\mathrm{A}$ and $\mathrm{B}$. It is possible that contamination of the TC preparations by GCs was responsible for the apparent expression of inhibin $\alpha$ in the TCs. In previous unpublished studies, we have shown minimal or absent expression of FSHR in the TCs prepared in exactly the same way as in this study, but we did not do this in this study. However, given the large difference in the threshold cycle $\left(C_{\mathrm{T}}\right)$ values for the QPCRs, in that the levels of inhibin $\alpha$ subunit mRNA were between three- and six-fold higher in the TCs than the GCs for the same follicle, this would suggest that the TC preparations would be contaminated with between three- and six-fold more GCs than TCs. This is not conceivable, but in future studies, FSHR mRNA levels will need to be examined as complete evidence of the minimal or absent contamination of the TC preparations. In our study, low levels of inhibin $\alpha$ protein were present in the thecal layer as well as GCs of preovulatory estrogenic follicles. Future studies will be required to determine the exact cell types that are expressing each 


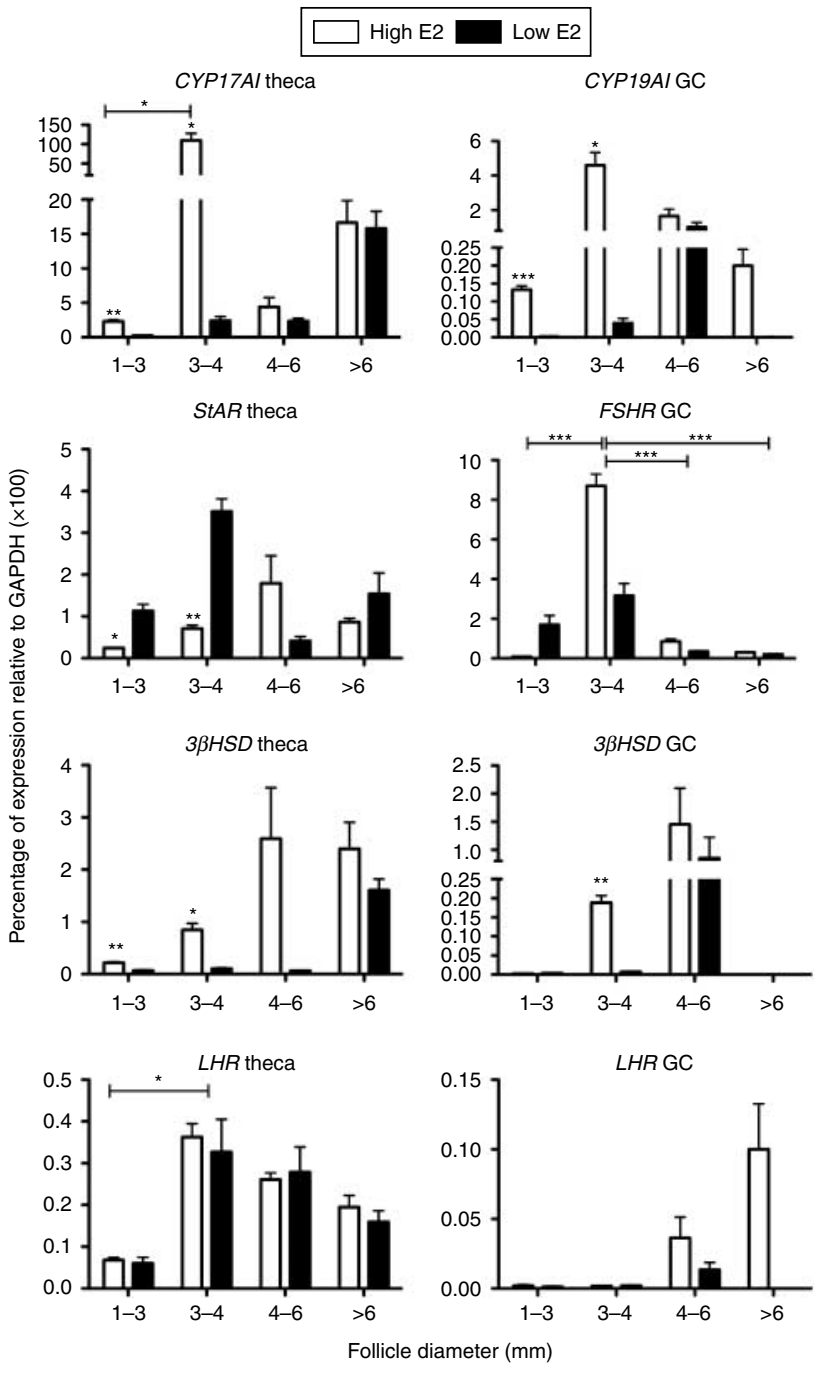

Figure 6 Follicles collected during anestrus. Gene expression levels for StAR, CYP17A1, 3BHSD, and LHR in theca cells and CYP19A1, FSHR, $3 \beta H S D$, and $L H R$ in granulosa cells (GC) are graphed. Follicles (1-3 to $>6 \mathrm{~mm}$ in diameter) were segregated based on FF estrogenic content (high (white bars) and low (black bars) estrogen) $\left({ }^{*} P<0.05,{ }^{* *} P<0.01\right.$, and $* * * P<0.001)$.

subunit and therefore potentially contributing to the inhibin that controls androgen production.

As follicles developed from small antral to large preovulatory follicles, dynamic switches in activin and inhibin subunit gene expression occurred. Several studies have previously looked at expression of $\beta A, \beta B$, and $\alpha$ subunits in follicles of human ovaries, and although not in complete agreement, the evidence indicates that various degrees of expression for all three subunits were found in GCs and TCs (Yamoto et al. 1992, 1993, Roberts et al. 1993, Jaatinen et al. 1994, Roberts \& Barth 1994). In adult monkey ovaries, the $\beta B$ subunit was observed in small antral follicles before $\alpha$ or $\beta A$ mRNA was detected (Schwall et al. 1990). Activin $\beta A$ and $\beta B$ subunit mRNA was detected in GCs and TCs from small porcine antral follicles (van den Hurk \& Van de Pavert 2001). In sheep ovaries, no inhibin $\alpha$ had previously been detected in TCs but was detected in GCs of some healthy antral follicles at all stages of the estrous cycle (Tisdall et al. 1994). In antral follicles expressing $\beta A$, the $\alpha$ subunit and follistatin were also always detected; however, the converse was not true. In preantral and atretic sheep follicles, no $\alpha$ or $\beta A$ was detected, but follistatin was present. Activin has been localized to oocytes and GCs in rodents, pigs, and cows (Hulshof et al. 1997, van den Hurk \& Van de Pavert 2001, Zhao et al. 2001) and in human GCs and TCs (Roberts et al. 1993). The effects of activin on follicular development are controversial where some studies have reported a stimulatory effect (Thomas et al. 2003, Silva et al. 2006, Telfer et al. 2008) and others indicated an inhibitory effect (Mizunuma et al. 1999, Knight et al. 2011).

Expression levels of activin receptors, betaglycan, follistatin, intracellular smads, and presence of the many TGF $\beta$ signaling antagonists have implications on efficacy of activin signal transduction (Knight et al. 2011, Scaramuzzi et al. 2011). For example, expression of the inhibin receptor betaglycan is higher in TCs than in GCs, and expression increased as follicle growth progressed in antral bovine follicles (Glister et al. 2010). Betaglycan is also in TCs and GCs of human follicles and in rodents (Drummond et al. 2002, Liu et al. 2003). In sheep, betaglycan was expressed in the oocytes of primordial follicles and in GCs and TCs of preantral follicles (McNatty et al. 2007). The presence of betaglycan in these cells indicates that TCs and GCs are target cells of inhibin, as betaglycan functions by mediating functional antagonism of activin signaling (Lewis et al. 2000). In cows, the expression of the type I activin receptor in TCs fell in large estrogenic follicles (Glister et al. 2010), suggesting an additional control mechanism for reducing activin signaling.

The results of this study suggest that synthesis of activin and inhibin subunits occurred at specific developmental time points throughout folliculogenesis, subsequently a corresponding amount of protein accumulated in the antral fluid of growing follicles. Follicles destined for ovulation synthesized greater levels of mRNA encoding activin $\beta A$ in TCs and GCs and inhibin $\alpha$ in TCs and had lower levels of activins $A$ and $B$ in the $F F$ of $>6 \mathrm{~mm}$ dominant follicles compared with subordinate follicles. We found that activins A and B suppressed androgen production in TCs, and inhibin blocks this suppressive effect. Therefore, in estrogenic follicles, higher production of activin $\beta A$ and activin $A$ at $3-4 \mathrm{~mm}$ in diameter suggests that androgen synthesis is being kept in check at this stage by activin A production. Once follicles reach gonadotrophin dependence and GCs of the selected preovulatory follicle(s) switch on aromatase (CYP19A1) expression to produce $E_{2}$, inhibin $\alpha$ mRNA is synthesized producing inhibin $A$ that functions to block the suppressive effects of activin on androgen production. The result would increase androgen synthesis, 

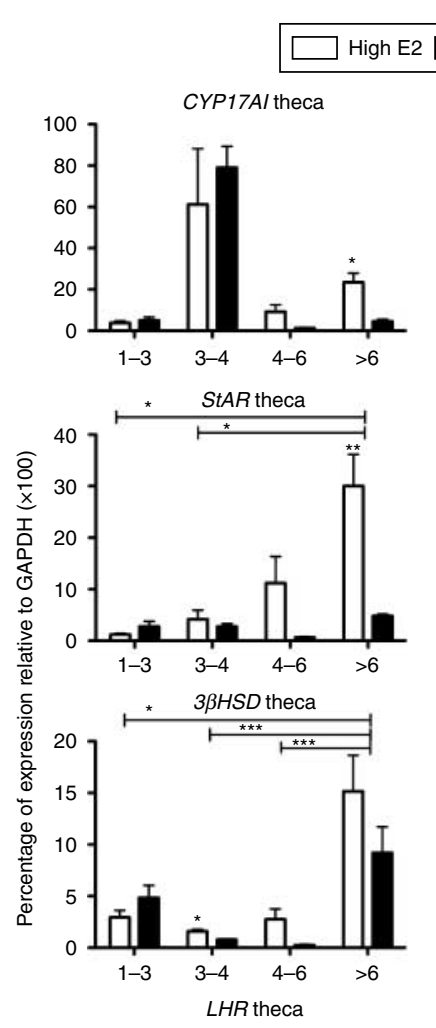

Low E2
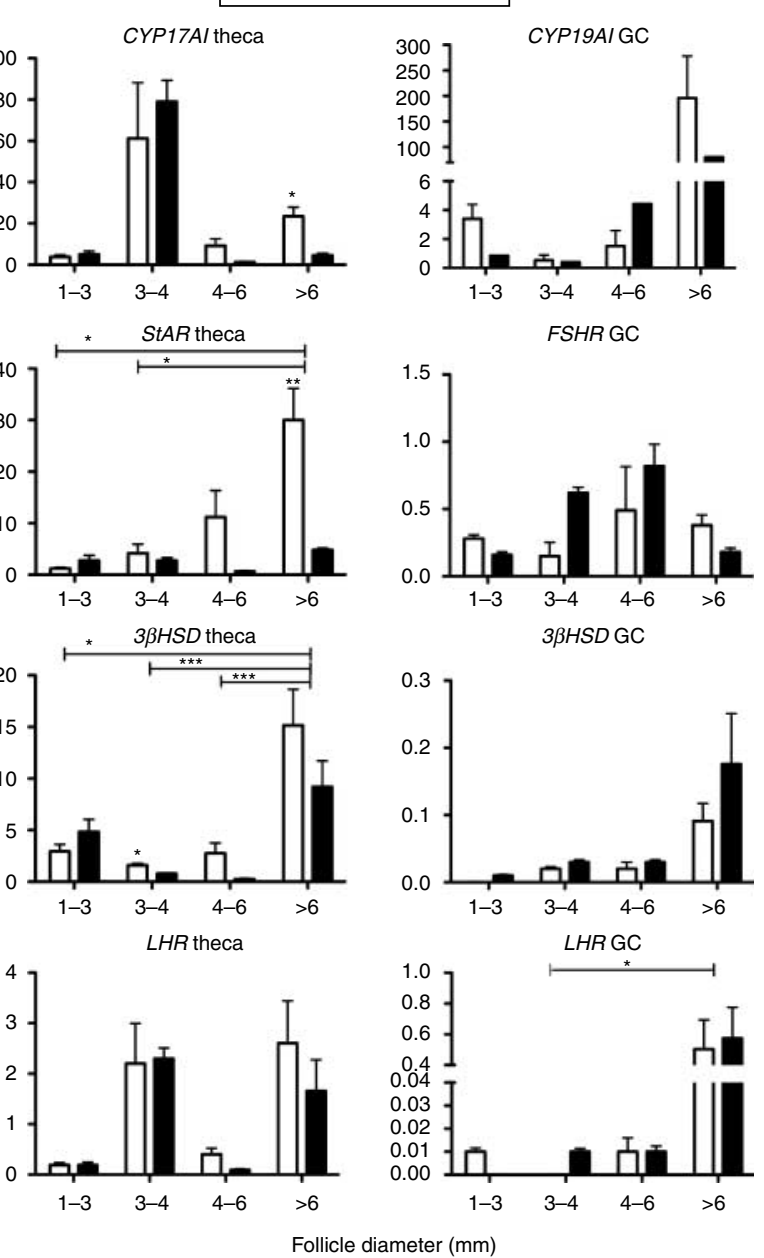

Figure 7 Follicles collected during the preovulatory phase of estrus. Gene expression levels for StAR, CYP17A1,3BHSD, and $L H R$ in theca cells and CYP19A1, FSHR, 3BHSD, and $L H R$ in granulosa cells (GC) are graphed. Follicles (1-3 to $>6 \mathrm{~mm}$ in diameter) were segregated based on FF estrogenic content (high (white bars) and low (black bars) estrogen) $\left({ }^{*} P<0.05,{ }^{* *} P<0.01\right.$, and $\left.{ }^{* * *} P<0.001\right)$.

which is required as a precursor for $E_{2}$ synthesis in neighboring GCs. However, it has previously been assumed that the increase in inhibin production was entirely produced by the GCs of the estrogenic follicle. In our study, it is clear that the TCs produce inhibin and thus a local TC-derived inhibin system is activated to enhance androgen production by blocking local activins A and B inhibition.

After ovulation, the secretion of $E_{2}$ and thecal androgens decreases dramatically (Baird et al. 1981). In this, the expression of inhibin $\alpha$ and activin $\beta A$ subunits in estrogenic follicles is also dramatically reduced to be equivalent to the level of nonestrogenic follicles shortly after the LH surge signaling ovulation. The maintained levels of $\alpha$ inhibin and activin $\beta A$ subunits producing inhibin $A$ and the maintained levels of inhibin $A$ in the FF of these follicles $>3 \mathrm{~mm}$ diameter after the preovulatory LH surge is in accordance with the maintained secretion of inhibin by the ovary after the preovulatory surge in sheep (McNeilly et al. 1989, Campbell et al. 1990).

No two follicles are in the same microenvironment of growth factors, contain the same numbers of GCs and TCs, or have the same blood supply at any one time (McNatty et al. 2007). These results show that there are differences in the levels of activin and inhibin subunit expression in TCs and GCs of follicles that are destined for ovulation in comparison to those that regress. In this study, we have assessed the expression levels of steroidogenic enzymes and pathway components in TCs and GCs. In general, all follicles 1-3 mm in diameter expressed mRNA encoding StAR, CYP17A1, and $3 \beta H S D$ in TCs and CYP19A1 in GCs. As follicles progressed along the developmental pathway, CYP17A1 expression levels increased dramatically in TCs of 3-4 mm follicles. This change signifies the point at which androgen production begins and CYP17A1 is a rate-limiting enzyme required for this process (Young \& McNeilly 2010). As expected, follicles during anestrus displayed reduced expression patterns of steroidogenic pathway components in comparison with the preovulatory follicular phase primarily due to the reduced LH pulse frequency in anestrus as normal steroid secretion can be induced by replacement of LH pulses alone (McNeilly et al. 1982, Wallace et al. 1986, McLeod \& McNeilly 1987).

Before the LH surge, TCs of estrogenic follicles $>6 \mathrm{~mm}$ in diameter produce more mRNA encoding CYP17A1 and StAR, and these levels dropped dramatically following the LH surge. This may be due to downregulation of $\mathrm{LH}$ receptors, and we have shown in this study that the LH surge also caused a reduced level of LHR expression in TCs of estrogenic follicles $>6 \mathrm{~mm}$ in diameter compared with subordinate follicles. In GCs of the same follicles, levels of CYP19A1 expression were high before the LH surge but then radically reduced following the LH surge. The fact that estrogenic follicles require greater amounts of androgen production in order to produce more $E_{2}$ supports this data, which showed higher expression levels of steroidogenic pathway components in both TCs and GCs before the LH surge. The reduction in steroid enzyme levels in both the TCs and GCs explains the dramatic reduction in secretion of $\mathrm{E}_{2}$ and androgens after the $\mathrm{LH}$ surge.

In summary, this is the first study showing that FF activin B protein levels are highest in small antral follicles and decrease as follicle size increased. Dominant preovulatory follicles had reduced amounts of FF activin B protein compared with subordinate follicles of the same size. In addition, the data showed the expression patterns of activin $\beta B$ subunit in TCs and GCs of antral follicles varied according to the estrogenic status of the follicle as well as the size and stage of the estrous cycle and anestrus. Furthermore, this study suggests, for the first time, that in sheep follicles, the 
TCs are able to synthesize all subunits required to produce activin $\mathrm{B}, \mathrm{A}$, and inhibin $\mathrm{A}$ in a controlled manner to autoregulate androgen production at the local TC level regardless of inhibin production by the GCs during follicular development.

\section{Materials and Methods}

\section{Follicle collection}

Ovaries were obtained from Scottish Blackface ewes in accordance with the UK Home Office Guideline and Project Licence approved by the local University of Edinburgh Ethical Review Process (ERP) and the Animals (Scientific Procedure) Act 1986. The ovaries from ten sheep were collected during the anestrus phase (July), and the estrous cycles in a further 20 sheep were synchronized by withdrawal of progestogen-impregnated
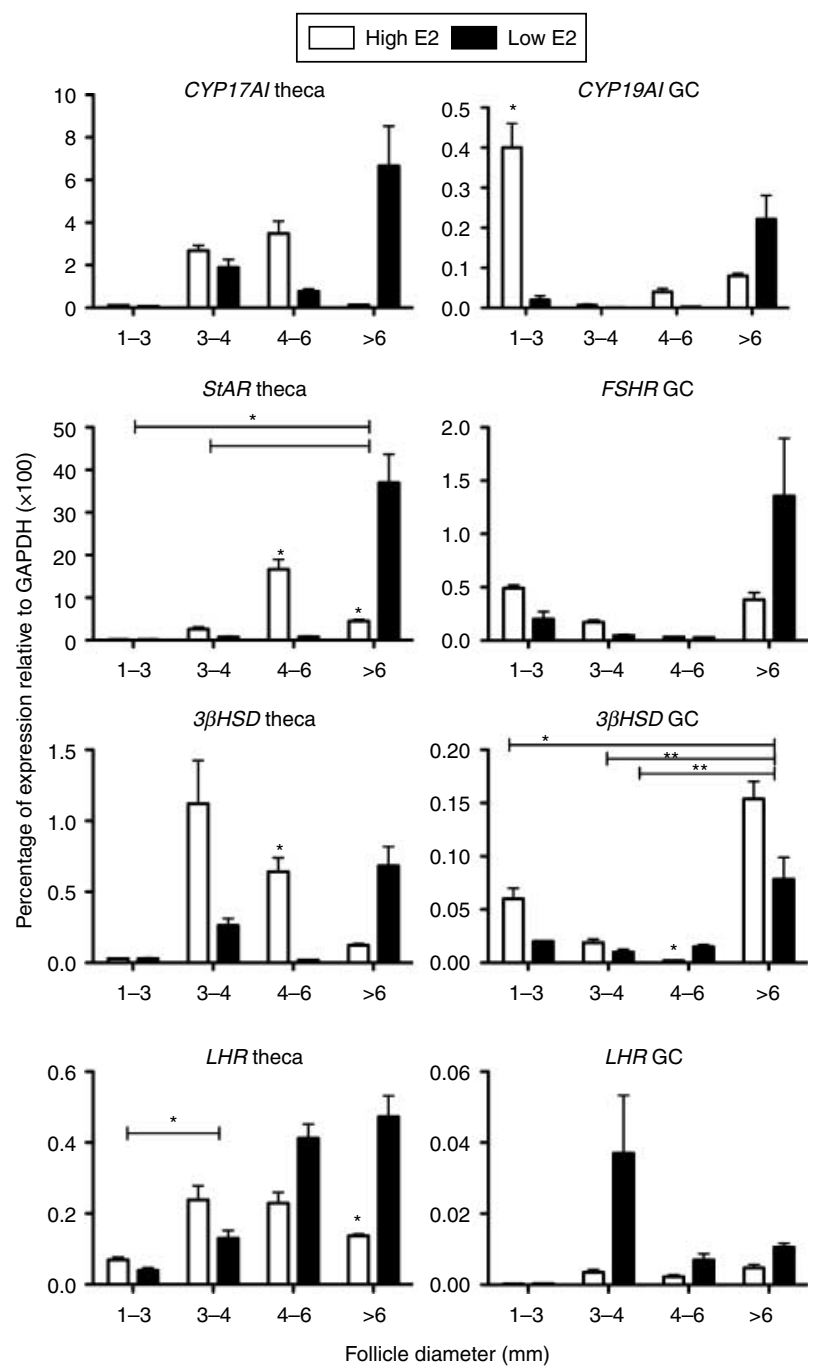

Figure 8 Follicles collected after the LH surge during estrus. Gene expression levels for StAR, CYP17A1, 3BHSD, and LHR in theca cells and CYP19A1, FSHR, 3BHSD, and $L H R$ in granulosa cells (GC) are graphed. Follicles (1-3 to $>6 \mathrm{~mm}$ in diameter) were segregated based on FF estrogenic content (high (white bars) and low (black bars) estrogen) $\left({ }^{*} P<0.05,{ }^{* *} P<0.01\right.$, and $\left.{ }^{* * *} P<0.001\right)$.

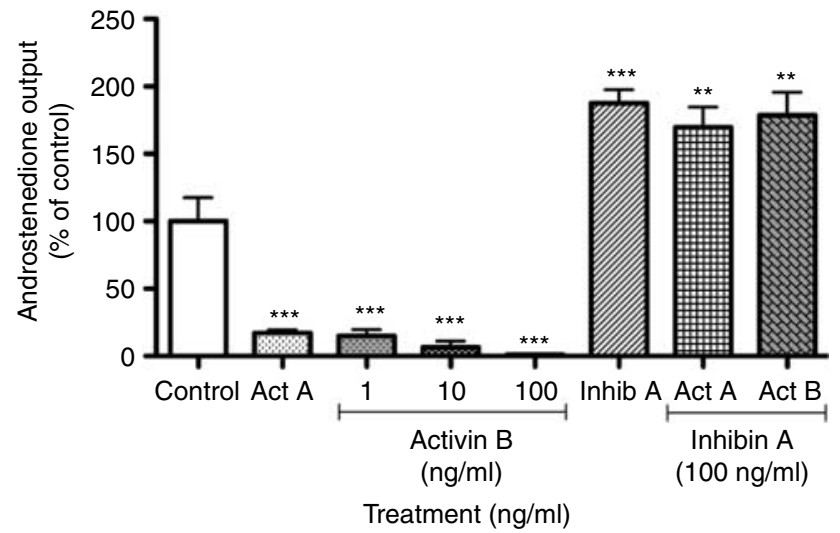

Figure 9 Reduced androstenedione production in the presence of activin B. Primary sheep theca cells were cultured in the presence of activin $A$ $(1 \mathrm{ng} / \mathrm{ml})$, activin $B(1,10$, and $100 \mathrm{ng} / \mathrm{ml})$, and inhibin $A(1 \mathrm{ng} / \mathrm{ml})$ and combinations of inhibin $(100 \mathrm{ng} / \mathrm{ml})$ and activin $\mathrm{A}(10 \mathrm{ng} / \mathrm{ml})$ or activin B $(10 \mathrm{ng} / \mathrm{ml})$. Cell culture media (serum-free) was replaced every $48 \mathrm{~h}$ over a $144 \mathrm{~h}$ culture period and androstenedione secreted into spent media evaluated by RIA. Results show average \pm S.E.M. of four replicates. Data provided are representative of at least four experiments, of which each experiment contained a separate pool of cells $(n=4-5$ sheep per pool) and significance calculated by Student's $t$-test $(* * P<0.01$ and ${ }^{* * *} P<0.001$ when compared with the control group).

sponges (60 mg medroxyprogesterone acetate per sponge; Intervet Laboratories Ltd, Cambridge, UK) in November. Luteolysis was induced on day 10 of the subsequent cycle using a synthetic PGF2 $\alpha$ analog (PG) (100 $\mu$ g i.m. Estrumate; Schering-Plough Animal Health, Welwyn Garden City, UK). Ovaries were collected $36 \mathrm{~h}$ after PG in the late follicular phase from ten sheep just before the LH surge and ten sheep $20 \mathrm{~h}$ after a preovulatory $\mathrm{LH}$ surge induced by the i.v. injection of GNRH agonist (500 $\mu \mathrm{g}$ Buserelin; Sanofi-Aventis, Guilford, UK; Crawford et al. 2000) just before ovulation. Follicles containing an antral cavity were dissected from the ovary and measured and then hemisected in individual wells. The GCs scraped and washed out from the theca shell into $1 \mathrm{ml}$ PBS and then centrifuged to separate the GCs from the FF. The FF/PBS solution from each individual follicle was stored at $-20^{\circ} \mathrm{C}$ for ELISA. The GCs from each individual follicle were then suspended in lysis buffer (RNeasy Micro kit, Qiagen) and individual theca shells placed in $200 \mu \mathrm{l}$ RNAlater (Qiagen) and stored at $-20^{\circ} \mathrm{C}$ for gene expression analyses.

\section{Immunohistochemistry for inhibin $\alpha$ and $\beta A$ subunit}

Sections from archived ovaries from two sheep collected in a previous study in the late follicular phase (at the same time as in this study, $36 \mathrm{~h}$ after PG) (Gubbay et al. 2006) were used to determine whether inhibin $\alpha$ and activin $\beta$ A subunits were present in the thecal layer of follicles. Follicles were classified as either estrogen positive and thus preovulatory or estrogen negative, on the basis of the presence or absence of P450 aromatase determined by immunohistochemistry.

Sections ( $5 \mu \mathrm{m}$ thickness) were dewaxed in xylene and rehydrated in decreasing concentrations of alcohol (100, 90, and $75 \%$ ). After a 5 min wash in water and another in $0.05 \mathrm{M}$ 
TBS, sections were blocked in $3 \% \mathrm{H}_{2} \mathrm{O}_{2}$ in methanol for $30 \mathrm{~min}$ to inhibit endogenous peroxidase activity. Following another wash in water $(5 \mathrm{~min})$ and TBS $(2 \times 5 \mathrm{~min})$, combined avidin-biotin block was performed according to the manufacturer's instructions (Vector Laboratories, Peterborough, UK). Nonspecific background was blocked for $30 \mathrm{~min}$ at room temperature with 10\% normal goat serum (Diagnostics Scotland, Carluke, UK) diluted 1:5 in TBS containing 5\% BSA. Slides were incubated with primary antibodies diluted in normal blocking serum at $4{ }^{\circ} \mathrm{C}$ overnight in a humidity chamber. Aromatase was detected using a primary antibody raised in mouse at 1:50 dilution and activin $\beta$ A by the $E 4$ mouse antibody also diluted to $1: 50$. Inhibin $\alpha$ primary antibody (PPG/14/6) was biotinylated and used at 1:100 dilution (source of antibodies (Ludlow et al. 2009)). Negative controls were performed by replacing the primary antibody with normal blocking serum. After washing in TBS $(2 \times 5 \mathrm{~min})$ to remove excess primary antibody slides were incubated with a biotinylated secondary antibody diluted 1:500 in normal serum for $30 \mathrm{~min}$. Inhibin $\alpha$ slides did not require a biotinylated secondary antibody as the primary antibody was biotinylated. After another wash cycle, all slides were incubated in streptavidin HRP (Vector Laboratories) diluted 1:1000 in TBS for $30 \mathrm{~min}$. Bound antibody was visualized using 3,3'diaminobenzidine tetrahydrochloride (Dako, Ely, Cambridgeshire, UK). Sections were counterstained with hematoxylin, dehydrated, mounted, and visualized by light microscopy.

\section{Primary TC culture}

Ovaries were obtained from sheep during random stages of the estrous cycle or in anestrus throughout the year and transferred to the laboratory in Medium199 containing $20 \mathrm{mmol} / \mathrm{l}$ HEPES, $100 \mathrm{kIU} / \mathrm{l}$ penicillin, $0.1 \mathrm{ng} / \mathrm{ml}$ streptomycin, and $1 \mathrm{mg} / \mathrm{l}$ amphotericin (Fungizone) (all supplied by Sigma-Aldrich). Small follicles (1-3.5 $\mathrm{mm}$ in diameter) were dissected from ovaries in Dulbecco's PBS without calcium or magnesium, with particular attention given to removal of all extraneous stromal tissues surrounding the thecal layers. Follicles were then hemisected and washed vigorously using a $1 \mathrm{ml}$ syringe, flushing repeatedly, to separate GCs from the theca shells as described previously (Campbell et al. 1998). The thecal shells were then dispersed in an enzyme mixture containing $10 \mathrm{ml}$ PBS, $5 \mathrm{~g} / \mathrm{l}$ collagenase, $1 \mathrm{~g} / \mathrm{l}$ hyaluronidase, $1 \mathrm{~g} / \mathrm{l}$ protease, and $0.001 \%$ donor calf serum (vol/vol), for $\sim 10 \mathrm{~min}$ at $37^{\circ} \mathrm{C}$ with gentle agitation. The reaction was stopped by addition of $2 \mathrm{ml} \mathrm{FCS}$, and cells were then washed by centrifugation at $800 \mathrm{~g}$ for $5 \mathrm{~min}$ and resuspended in culture media (DMEM-F12 with $100 \mathrm{kIU} / \mathrm{l}$ penicillin, $0.1 \mu \mathrm{g} / \mathrm{l}$ streptomycin, $3 \mathrm{mmol} / \mathrm{I}$ L-glutamine, $0.1 \%$ BSA (w/vol), $2.5 \mathrm{mg} / \mathrm{l}$ transferrin, $4 \mu \mathrm{g} / \mathrm{l}$ selenium, $10 \mathrm{ng} / \mathrm{ml}$ bovine insulin, $0.1 \mathrm{ng} / \mathrm{ml}$ ovine $\mathrm{LH}$ (code\# AFP 8614B-NHPP-NIDDK supplied by Dr A Parlow, NHPP, Harbor-UCLA, Torrance, CA, USA) and $10 \mathrm{ng} / \mathrm{ml}$ LR3 IGF1). The cell pellets were then resuspended in culture media and after a further wash, the number and viability of cells was estimated using Trypan Blue exclusion. Cell viability was routinely more than $95 \%$.

Cells were plated in 96-well plates at 75000 cells in a total of $200 \mu \mathrm{l}$ media per well. Activin A (code\# 338-AC) and activin B (code\# 659-AB) were obtained from R\&D Systems (Abingdon, Oxon, UK) and inhibin A from NIBSC (code \# 91/624, Hertfordshire, UK). Cells were cultured under standard culture conditions consisting of a humidified atmosphere with $5 \% \mathrm{CO}_{2}$ at $37^{\circ} \mathrm{C}$. For hormone analysis, cells were cultured for up to 6 days and media changed every $48 \mathrm{~h}$ and stored at $-20{ }^{\circ} \mathrm{C}$ for analysis at a later stage. At the end of the culture period, the cell viability was determined by neutral red dye uptake, as described elsewhere (Campbell et al. 1998).

\section{Immunoassays}

\section{RIA}

Concentrations of androstenedione were determined from nonextracted cell culture media using previously described RIA methods (Campbell et al. 1998). The sensitivity of the androstenedione assay was $\sim 5 \mathrm{pg} / \mathrm{ml}$ and inter- and intra-assay variation was $<15 \%$. Each experiment was repeated at least three times with a separate pool of cells taken from different animals ( $n \geq 4$ animals in each pool of cells).

The significance of treatment effects was determined using Student's $t$-test. The data shown is representative of replicated experiments and is presented as a percentage of the control androstenedione production with significance levels indicated (**P $<0.01$ and $\left.{ }^{* * *} P<0.001\right)$.

\section{ELISA}

FF concentrations of $E_{2}$, activin $A$, activin $B$, and inhibin $A$ were measured using ELISA. Activin B concentrations were measured using the activin B ELISA that incorporates the use

Table 1 Primer sequences used for QPCR assays and amplicon sizes.

\begin{tabular}{|c|c|c|c|}
\hline Gene (accession) & Forward primer $\left(5^{\prime}-3^{\prime}\right)$ & Reverse primer $\left(5^{\prime}-3^{\prime}\right)$ & Insert size $(b p)$ \\
\hline GAPDH (NM_001034034) & GGCGTGAACCACGAGAAGTATAA & AAGCAGGGATGATGTTCTGG & 229 \\
\hline StAR (NM_001009243) & GCATCCTCAAAGACCAGGAG & СTTGACACTGGGGTTCCACT & 194 \\
\hline CYP17A1 (NM_001009483) & AGACATATTCCCTGCGCTGA & GCAGCTTTGAATCCTGCTCT & 215 \\
\hline 3ßHSD (NM_001135932) & GGAGACATTCTGGATGAGCAG & TCTATGGTGCTGGTGTGGA & 200 \\
\hline CYP19A1 (NM_001123000) & AATCCAGCACTCTGGAAAGC & ACGTCCACATAGCCCAAGTC & 152 \\
\hline Activin BA (NM_174363.1) & GAAGAGACCCGATGTCACCCAGC & TGTCGTCCTCTATCTCCACGTACCCG & 113 \\
\hline Activin BB (NM_176852.1) & ATGGССТGGССТССТСССG & CTTCAGGTAGAGCCACAGGCTGGC & 101 \\
\hline Inhibin $\propto$ (NM_174094.3) & GAGCCCGAGGACCAAGATGTCTCC & ССТСАGССТСТССАGСАТСТGGC & 91 \\
\hline LHR (NM_2144449) & TCCGAAAGCTTCCAGATGTT & GAAATCAGCGTTGTCCCATT & 199 \\
\hline FSHR (NM_001009289) & TAAGCACTTGCCAGCTGTTC & CTCATCGAGTTGGGTTCCAT & 196 \\
\hline
\end{tabular}


of $\mathrm{MAB} 46 \mathrm{~A} / \mathrm{F}$ as both the capture and the detection antibody (Ludlow et al. 2009). This assay also uses a SDS and heat pretreatment step to remove any binding proteins that may interfere. The FF of each individual follicle was diluted into PBS when extracted from follicles, and this diluted sample was added directly to the assay. The assay had a lower detection limit of $19 \mathrm{pg} / \mathrm{ml}$.

Inhibin A concentrations in FF were measured using a plate modification of a standard in-house inhibin A ELISA as described previously with a sensitivity of $2 \mathrm{pg} / \mathrm{ml}$ and an intra- and interplate coefficients of variation $<10 \%$ (McNeilly et al. 2002). Activin A concentrations were measured using a two-site ELISA kit that measured total activin A (Knight et al. 1996; Oxford Bio-Innovation, Oxfordshire, UK), following the manufacturer's instructions. This assay had a sensitivity $<78 \mathrm{pg} / \mathrm{ml}$ and inter- and intraplate coefficients of variation $<10 \%$.

An in-house ELISA was used to measure $E_{2}$ in ovine FF. Briefly, 96 microwell plates were precoated with donkey antisheep IgG (1:200; 713-005-147; Jackson ImmunoResearch, Suffolk, UK). Plates were sealed and stored overnight at $4{ }^{\circ} \mathrm{C}$ in a humidity chamber. On day 2, coating buffer was discarded and the plate washed thoroughly with wash buffer (deionized water $+0.1 \%$ Tween-20). $E_{2}$ antibody (In-house ASMR32; 1:300 000, diluted in PGBS) was added to each well and incubated for $3 \mathrm{~h}$ at room temperature. The liquid was discarded and the plate washed repeatedly. The dilution of FF ranged from $1: 2$ to $1: 100$. The appropriate controls and standards (7.8-1000 pg/ml; E8875, Sigma) were run in parallel and the assay carried out in duplicate. In-house $E_{2}$ tracer conjugated to HRP was diluted 1:500 in PGBS and incubated with the sample for $2 \mathrm{~h}$ at room temperature followed by washing steps. Substrate, $0.1 \mathrm{M}$ citrate phosphate buffer $\mathrm{pH} 5.0,0.03 \% \mathrm{v} / \mathrm{v}$ hydrogen peroxide, and $0.1 \% \mathrm{w} / \mathrm{v}$ o-phenylenediamine dihydrochloride, was added to each well. The plate was wrapped in foil, incubated for $30 \mathrm{~min}$ at room temperature, and the reaction stopped with the addition of concentrated sulfuric acid diluted 1:10 in deionized water. Spectrophotometry was subsequently performed at $495 \mathrm{~nm}$. The intra- and interassay CV were 6.7 and $10 \%$ respectively. $\mathrm{E}_{2}$ values $1-30 \mathrm{ng} /$ follicle were regarded as low and those follicles were classified as nonestrogenic. Estrogenic follicles were determined by values $\geq 30 \mathrm{ng} /$ follicle.

The actual concentration of each protein measured in the FF was calculated by accounting for the initial dilution of the FF into $1 \mathrm{ml}$ PBS when being dissected and then by using the follicle diameter measurement an estimate of the volume of FF contained in each follicle was calculated.

\section{Quantitative RT-PCR}

The GCs and TCs from all follicles isolated were sorted according to the content of $E_{2}$ measured from the FF collected. The five follicles with the highest and five with the lowest levels of $E_{2}$ within each size group (1-3,3-4, 4-6, and $>6 \mathrm{~mm}$ diameter) for each phase of the cycle (anestrus, before $\mathrm{LH}$ surge, and after LH surge) were then selected for gene expression studies. Each follicle was treated separately, and no pooling of RNA or FF from individual follicles was carried out within this study.

The GCs from each individual follicle were lysed using passive lysis buffer (PLB; Qiagen RNeasy Micro RNA extraction kit), and each individual theca shell was transferred from RNAlater into PLB and lysed in a tissue lyser (Qiagen). RNA was extracted using the RNeasy Micro RNA extraction Kit, and RNA concentration and purity $\left(\mathrm{A}_{260}: \mathrm{A}_{280}\right.$ ratio $)$ were measured using a NanoDrop 1000 spectrophotometer (Thermo Fisher Scientific, Loughborough, Leicestershire, UK). RNA was stored at $-80{ }^{\circ} \mathrm{C}$ until cDNA was synthesized from $200 \mathrm{ng}$ total RNA per reaction using Superscript VILO cDNA synthesis kit (Invitrogen) in a $20 \mu$ l reaction.

Primer sets for expression analysis were designed to amplify short regions of the target genes crossing an intron/exon boundary and are described in Table 1 . The primers were prevalidated using conventional PCR and the product was sequenced to confirm authenticity. Quantitative RT-PCR was carried out using PowerSYBR Green (Applied Biosystems, Paisley, Renfrewshire, UK), whereby primer efficiency was determined by generating standard curves. A $10 \mu \mathrm{l}$ final reaction volume was prepared using $1 \mu \mathrm{l}$ synthesized cDNA, $2 \times$ PowerSYBR Green PCR Master Mix, $5 \mu \mathrm{M}$ primer pairs, and nuclease-free water. The qRT-PCR cycling program consisted of a denaturing step $\left(95^{\circ} \mathrm{C}\right.$ for $\left.10 \mathrm{~min}\right)$, annealing, and extension step $\left(95^{\circ} \mathrm{C}\right.$ for $15 \mathrm{~s}, 60{ }^{\circ} \mathrm{C}$ for $\left.1 \mathrm{~min}\right)$ repeated 40 times, and a dissociation step $\left(95,60\right.$, and $95^{\circ} \mathrm{C}$ for $15 \mathrm{~s}$ each), using a real-time thermal cycler from Applied Biosystems (ABI7500). Each sample was measured in duplicate and negative controls included a reaction using cDNA prepared leaving out reverse transcriptase and a reaction substituting cDNA with nuclease-free water.

The relative expression level of each target gene was normalized to that of the housekeeping gene GAPDH for each individual sample/follicle and was quantified using the $\Delta \Delta C_{\mathrm{t}}$ method.

\section{Statistical analysis}

Data are presented as average \pm s.E.M. and the statistical analysis was performed using GraphPad Prism version 4.0 (GraphPad Software, Inc., San Diego, CA, USA) using an unpaired Student's $t$-test to compare the means of two groups or ANOVA for more than two groups. $P$ values $<0.05$ were regarded as significant, and levels of significance are indicated on graphs for each gene analyzed $\left({ }^{*} P<0.05, * * P<0.01\right.$, and ***P<0.001).

\section{Declaration of interest}

The authors declare that there is no conflict of interest that could be perceived as prejudicing the impartiality of the research reported.

\section{Funding}

This study was supported by a MRC grant to A S McNeilly (G00007.01). 


\section{Acknowledgements}

We would like to thank Kirsten Hogg for QPCR primers and staff at the Marshall Building, University of Edinburgh for support and care of the animals.

\section{References}

Baird DT, Swanston IA \& McNeilly AS 1981 Relationship between LH, FSH, and prolactin concentration and the secretion of androgens and estrogens by the preovulatory follicle in the ewe. Biology of Reproduction 24 1013-1025. (doi:10.1095/biolreprod24.5.1013)

Bernard DJ, Lee KB \& Santos MM 2006 Activin B can signal through both ALK4 and ALK7 in gonadotrope cells. Reproductive Biology and Endocrinology 4 52. (doi:10.1186/1477-7827-4-52)

Brown CW, Houston-Hawkins DE, Woodruff TK \& Matzuk MM 2000 Insertion of Inhbb into the Inhba locus rescues the Inhba-null phenotype and reveals new activin functions. Nature Genetics 25 453-457. (doi:10.1038/78161)

Campbell BK, Mann GE, McNeilly AS \& Baird DT 1990 The pattern of ovarian inhibin, estradiol, and androstenedione secretion during the estrous cycle of the ewe. Endocrinology 127 227-235. (doi:10.1210/ endo-127-1-227)

Campbell BK, Baird DT \& Webb R 1998 Effects of dose of LH on androgen production and luteinization of ovine theca cells cultured in a serum-free system. Journal of Reproduction Fertility 112 69-77. (doi:10.1530/jrf.0. 1120069)

Carson RS, Findlay JK, Clarke IJ \& Burger HG 1981 Estradiol, testosterone, and androstenedione in ovine follicular fluid during growth and atresia of ovarian follicles. Biology of Reproduction 24 105-113. (doi:10.1095/ biolreprod24.1.105)

Corrigan AZ, Bilezikjian LM, Carroll RS, Bald LN, Schmelzer CH, Fendly BM, Mason AJ, Chin WW, Schwall RH \& Vale W 1991 Evidence for an autocrine role of activin B within rat anterior pituitary cultures. Endocrinology 128 1682-1684. (doi:10.1210/endo-128-3-1682)

Crawford JL, Currie RJ \& McNeilly AS 2000 Replenishment of LH stores of gonadotrophs in relation to gene expression, synthesis and secretion of $\mathrm{LH}$ after the preovulatory phase of the sheep oestrous cycle. Journal of Endocrinology 167 453-463. (doi:10.1677/joe.0.1670453)

Drummond AE, Le MT, Ethier JF, Dyson M \& Findlay JK 2002 Expression and localization of activin receptors, Smads, and beta glycan to the postnatal rat ovary. Endocrinology 143 1423-1433. (doi:10.1210/en. 143.4.1423)

Glister C, Satchell L \& Knight PG 2010 Changes in expression of bone morphogenetic proteins (BMPs), their receptors and inhibin co-receptor betaglycan during bovine antral follicle development: inhibin can antagonize the suppressive effect of BMPs on thecal androgen production. Reproduction 140 699-712. (doi:10.1530/REP-10-0216)

Gubbay O, Rae MT, McNeilly AS, Donadeu FX, Zeleznik AJ \& Hillier SG 2006 cAMP response element-binding (CREB) signalling and ovarian surface epithelial cell survival. Journal of Endocrinology 191 275-285. (doi:10.1677/joe.1.06928)

Hillier SG, Yong EL, Illingworth PJ, Baird DT, Schwall RH \& Mason AJ 1991 Effect of recombinant activin on androgen synthesis in cultured human thecal cells. Journal of Clinical Endocrinology and Metabolism 72 1206-1211. (doi:10.1210/jcem-72-6-1206)

Hulshof SC, Figueiredo JR, Beckers JF, Bevers MM, Vanderstichele H \& van den Hurk R 1997 Bovine preantral follicles and activin: immunohistochemistry for activin and activin receptor and the effect of bovine activin A in vitro. Theriogenology 48 133-142. (doi:10.1016/S0093691X(97)00196-9)

van den Hurk R \& Van de Pavert SA 2001 Localization of an activin/activin receptor system in the porcine ovary. Molecular Reproduction and Development 60 463-471. (doi:10.1002/mrd.1111)

Jaatinen TA, Penttila TL, Kaipia A, Ekfors T, Parvinen M \& Toppari J 1994 Expression of inhibin alpha, beta $A$ and beta $B$ messenger ribonucleic acids in the normal human ovary and in polycystic ovarian syndrome. Journal of Endocrinology 143 127-137. (doi:10.1677/joe.0.1430127)
Knight PG \& Glister C 2006 TGF-beta superfamily members and ovarian follicle development. Reproduction 132 191-206. (doi:10.1530/rep.1. 01074)

Knight PG, Muttukrishna S \& Groome NP 1996 Development and application of a two-site enzyme immunoassay for the determination of 'total' activin-A concentrations in serum and follicular fluid. Journal of Endocrinology 148 267-279. (doi:10.1677/joe.0.1480267)

Knight PG, Satchell L \& Glister C 2011 Intra-ovarian roles of activins and inhibins. Molecular and Cellular Endocrinology.

Lewis KA, Gray PC, Blount AL, MacConell LA, Wiater E, Bilezikjian LM \& Vale W 2000 Betaglycan binds inhibin and can mediate functional antagonism of activin signalling. Nature 404 411-414. (doi:10.1038/ 35006129)

Liu J, Kuulasmaa T, Kosma VM, Butzow R, Vanttinen T, HydenGranskog C \& Voutilainen R 2003 Expression of betaglycan, an inhibin coreceptor, in normal human ovaries and ovarian sex cord-stromal tumors and its regulation in cultured human granulosa-luteal cells. Journal of Clinical Endocrinology and Metabolism 88 5002-5008. (doi:10.1210/jc.2003-030704)

Ludlow H, Phillips DJ, Myers M, McLachlan RI, de Kretser DM, Allan CA, Anderson RA, Groome NP, Hyvonen M, Colin Duncan W et al. 2009 A new 'total' activin B enzyme-linked immunosorbent assay (ELISA): development and validation for human samples. Clinical Endocrinology 71 867-873. (doi:10.1111/j.1365-2265.2009.03567.x)

Mathews LS \& Vale WW 1991 Expression cloning of an activin receptor, a predicted transmembrane serine kinase. Cell 65 973-982. (doi:10. 1016/0092-8674(91)90549-E)

Matzuk MM, Kumar TR \& Bradley A 1995 Different phenotypes for mice deficient in either activins or activin receptor type II. Nature $\mathbf{3 7 4}$ 356-360. (doi:10.1038/374356a0)

McLeod BJ \& McNeilly AS 1987 Suppression of plasma FSH concentrations with bovine follicular fluid blocks ovulation in $\mathrm{GnRH}$-treated seasonally anoestrous ewes. Journal of Reproduction and Fertility 81 187-194. (doi:10.1530/jrf.0.0810187)

McNatty KP, Reader K, Smith P, Heath DA \& Juengel JL 2007 Control of ovarian follicular development to the gonadotrophin-dependent phase: a 2006 perspective. Society of Reproduction and Fertility Supplement $\mathbf{6 4}$ 55-68.

McNeilly AS \& Fraser HM 1987 Effect of gonadotrophin releasing hormone agonist-induced suppression of $\mathrm{LH}$ and FSH on follicle growth and corpus luteum function in the ewe. Journal of Endocrinology $\mathbf{1 1 5}$ 273-282. (doi:10.1677/joe.0.1150273)

McNeilly AS, O'Connell M \& Baird DT 1982 Induction of ovulation and normal luteal function by pulsed injections of luteinizing hormone in anestrous ewes. Endocrinology 110 1292-1299. (doi:10.1210/endo110-4-1292)

McNeilly AS, Jonassen JA \& Fraser HM 1986 Suppression of follicular development after chronic LHRH immunoneutralization in the ewe. Journal of Reproduction and Fertility 76 481-490. (doi:10.1530/jrf.0. 0760481)

McNeilly AS, Jonassen JA \& Rhind SM 1987 Reduced ovarian follicular development as a consequence of low body condition in ewes. Acta Endocrinologica 115 75-83.

McNeilly AS, Swanston IA, Crow W, Tsonis CG \& Baird DT 1989 Changes in the plasma concentrations of inhibin throughout the normal sheep oestrous cycle and after the infusion of FSH. Journal of Endocrinology 120 295-305. (doi:10.1677/joe.0.1200295)

McNeilly AS, Picton HM, Campbell BK \& Baird DT 1991 Gonadotrophic control of follicle growth in the ewe. Journal of Reproduction and Fertility. Supplement 43 177-186.

McNeilly AS, Souza CJ, Baird DT, Swanston IA, McVerry J, Crawford J, Cranfield M \& Lincoln GA 2002 Production of inhibin A not B in rams: changes in plasma inhibin $A$ during testis growth, and expression of inhibin/activin subunit mRNA and protein in adult testis. Reproduction 123 827-835. (doi:10.1530/rep.0.1230827)

McNeilly AS, Crawford JL, Taragnat C, Nicol L \& McNeilly JR 2003 The differential secretion of $\mathrm{FSH}$ and $\mathrm{LH}$ : regulation through genes, feedback and packaging. Reproduction. Supplement 61 463-476.

Mizunuma H, Liu X, Andoh K, Abe Y, Kobayashi J, Yamada K, Yokota H, Ibuki Y \& Hasegawa Y 1999 Activin from secondary follicles causes small preantral follicles to remain dormant at the resting stage. Endocrinology 140 37-42. (doi:10.1210/en.140.1.37) 
Nakamura T, Asashima M, Eto $Y$, Takio K, Uchiyama H, Moriya N, Ariizumi T, Yashiro T, Sugino K, Titani K et al. 1992 Isolation and characterization of native activin B. Journal of Biological Chemistry $\mathbf{2 6 7}$ 16385-16389.

Padmanabhan V \& McNeilly AS 2001 Is there an FSH-releasing factor? Reproduction 121 21-30. (doi:10.1530/rep.0.1210021)

Pangas SA, Jorgez CJ, Tran M, Agno J, Li X, Brown CW, Kumar TR \& Matzuk MM 2007 Intraovarian activins are required for female fertility. Molecular Endocrinology 21 2458-2471. (doi:10.1210/me.2007-0146)

Roberts VJ \& Barth SL 1994 Expression of messenger ribonucleic acids encoding the inhibin/activin system during mid- and late-gestation rat embryogenesis. Endocrinology 134 914-923. (doi:10.1210/en.134. 2.914)

Roberts VJ, Barth S, el-Roeiy A \& Yen SS 1993 Expression of inhibin/activin subunits and follistatin messenger ribonucleic acids and proteins in ovarian follicles and the corpus luteum during the human menstrual cycle. Journal of Clinical Endocrinology and Metabolism 77 1402-1410. (doi:10.1210/jc.77.5.1402)

Scaramuzzi RJ, Adams NR, Baird DT, Campbell BK, Downing JA, Findlay JK, Henderson KM, Martin GB, McNatty KP, McNeilly AS et al. $1993 \mathrm{~A}$ model for follicle selection and the determination of ovulation rate in the ewe. Reproduction, Fertility, and Development 5 459-478. (doi:10.1071/RD9930459)

Scaramuzzi RJ, Baird DT, Campbell BK, Driancourt MA, Dupont J, Fortune JE, Gilchrist RB, Martin GB, McNatty KP, McNeilly AS et al. 2011 Regulation of folliculogenesis and the determination of ovulation rate in ruminants. Reproduction, Fertility, and Development 23 444-467. (doi:10.1071/RD09161)

Schwall RH, Mason AJ, Wilcox JN, Bassett SG \& Zeleznik AJ 1990 Localization of inhibin/activin subunit mRNAs within the primate ovary. Molecular Endocrinology 4 75-79. (doi:10.1210/mend-4-1-75)

Silva JR, Tharasanit T, Taverne MA, van der Weijden GC, Santos RR, Figueiredo JR \& van den Hurk R 2006 The activin-follistatin system and in vitro early follicle development in goats. Journal of Endocrinology $\mathbf{1 8 9}$ 113-125. (doi:10.1677/joe.1.06487)

Telfer EE, McLaughlin M, Ding C \& Thong KJ 2008 A two-step serum-free culture system supports development of human oocytes from primordial follicles in the presence of activin. Human Reproduction 23 1151-1158. (doi:10.1093/humrep/den070)

Thomas FH, Armstrong DG \& Telfer EE 2003 Activin promotes oocyte development in ovine preantral follicles in vitro. Reproductive Biology and Endocrinology 1 76. (doi:10.1186/1477-7827-1-76)
Tisdall DJ, Hudson N, Smith P \& McNatty KP 1994 Localization of ovine follistatin and alpha and beta A inhibin mRNA in the sheep ovary during the oestrous cycle. Journal of Molecular Endocrinology 12 181-193. (doi:10.1677/jme.0.0120181)

Vassalli A, Matzuk MM, Gardner HA, Lee KF \& Jaenisch R 1994 Activin/inhibin beta B subunit gene disruption leads to defects in eyelid development and female reproduction. Genes and Development 8 414-427. (doi:10.1101/gad.8.4.414)

Wallace JM, McNeilly AS \& Baird DT 1986 Induction of ovulation during anoestrus in two breeds of sheep with multiple injections of $\mathrm{LH}$ alone or in combination with FSH. Journal of Endocrinology 111 181-190. (doi:10.1677/joe.0.1110181)

Wallace JM, Martin GB \& McNeilly AS 1988 Changes in the secretion of LH pulses, FSH and prolactin during the preovulatory phase of the oestrous cycle of the ewe and the influence of treatment with bovine follicular fluid during the luteal phase. Journal of Endocrinology 116 123-135. (doi:10.1677/joe.0.1160123)

Webb R \& England BG 1982 Relationship between LH receptor concentrations in thecal and granulosa cells and in-vivo and in-vitro steroid secretion by ovine follicles during the preovulatory period. Journal of Reproduction and Fertility 66 169-180. (doi:10.1530/jrf.0. 0660169)

Yamoto M, Minami S, Nakano R \& Kobayashi M 1992 Immunohistochemical localization of inhibin/activin subunits in human ovarian follicles during the menstrual cycle. Journal of Clinical Endocrinology and Metabolism 74 989-993. (doi:10.1210/jc.74.5.989)

Yamoto M, Minami S \& Nakano R 1993 Immunohistochemical localization of inhibin subunits in polycystic ovary. Journal of Clinical Endocrinology and Metabolism 77 859-862. (doi:10.1210/jc.77.3.859)

Young JM \& McNeilly AS 2010 Theca: the forgotten cell of the ovarian follicle. Reproduction 140 489-504. (doi:10.1530/REP-10-0094)

Zhao J, Taverne MA, van der Weijden GC, Bevers MM \& van den Hurk $\mathbf{R}$ 2001 Effect of activin A on in vitro development of rat preantral follicles and localization of activin A and activin receptor II. Biology of Reproduction 65 967-977. (doi:10.1095/biolreprod65.3.967)

Received 1 September 2011

First decision 26 September 2011

Revised manuscript received 16 March 2012

Accepted 19 March 2012 